\title{
ECONOMIC IMPACT OF PEOPLE'S PARTICIPATION IN FOREST MANAGEMENT (A CASE STUDY OF KABHRE PALANCHWOK, NEPAL)
}

\author{
Yogesh Ranjit, PhD.*
}

\begin{abstract}
Forests as important renewable natural resources provide direct and indirect benefits to the people. Basically, it provides basic products of timber, poles, fuel wood, twigs, fodder, grass, leaf litter, and non-timber forest products (NTFPs) for the use of construction work, agriculture, livestock keeping, and forest based industries, etc. Similarly, a proper use of forests, forest products, and sustainable management could also contribute to income and employment generation and thereby reduction in the level of poverty of the nation. In addition, forests also provide vital role for bio-diversity conservation, environmental protection and ecological balance of the nation. Historically, people's participation in forest protection and management work is very old through many informal traditional and indigenous forest management committees. But it has formally and legally been recognized only since mid of 1970's through various forest plans, policies, acts, regulation and guidelines. The major aims of people's participation are for basic forest products, socio-economic development, and overall improvement of forest resources in which the government and I/NGOs could also help significantly.
\end{abstract}

Key words: Forest and natural resources, forest products, economic benefits, people's participation, socio-economic development, forest policies, Kabhre Palanchwok, Nepal.

\section{BACKGROUND}

Forest is the second largest natural resource of Nepal after the water resource that becomes only $29.0 \%\left(42,688 \mathrm{~km}^{2}\right)$ and shrub area covers $10.6 \%\left(15,592 \mathrm{~km}^{2}\right)$ of the total geographical area of the nation (DoF, 1999). Forests are very important renewable natural resources that could play a very significant role in the process of economic growth and development of the nation like Nepal. It has both direct and indirect benefits. The direct economic benefits are the various types of forest products for different uses like timber and poles for the construction of building, agricultural tools, and shed for livestock; fuel wood for energy; fodder, grass and leaf litter for livestock rearing and preparation of compost fertilizer; bamboo and thatching for roofing; medicinal plants for pesticides; and other non-timber forest products (NTFPs) for income and employment generation. Besides, forests are the natural habitat of various types of flora and fauna that consists of bio-diversity of plants, birds, wild animals, mammals, reptiles, and insects etc. So, the government has declared certain areas of the national forests as buffer zones, protected areas, national parks and wild

* Mr. Ranjit is Lecturer, Department of Economics, Patan Multiple Campus, T.U. 
life sanctuaries which could play a vital role in the development of eco-tourism and environmental protection. Forests are also being highly used for livestock grazing. The next economic benefits of forestry are the conversion of forestland to farmland and settlement areas but it has not been put under priority of any nation.

Forest becomes an important source for income and employment generation basically to the people living in and around the forests. It provides raw materials for forest based industries like timber, paper, plywood, furniture, match, and bidi (cigarette made of leaf) industry, resin tapping, rearing silk warms, rope making, oil extraction, making bowls and plates of broad leaf, netting mates and baskets of bamboo etc. Therefore, a proper use of forest products, well conservation, and sustainable management could also contribute to poverty reduction of the nation as well.

Historically, people's participation in forest protection and management work in Nepal is very common. There were various types of informal traditional forest management activities undertaken by the indigenous autonomous local committees in view of physical, socio-economic, religious, cultural and environmental importance. But, there were no any formal forest management policies of the government of Nepal due to small size of population and sufficient availability of forest resources. On the contrary, the government policy was to encourage the people to convert the forestland to agriculture land in order to increase the land-tax revenue of the government. However, people's participation has formally and legally been recognized by the government only since mid of 1970's by formulating various forest plans, policies, acts, regulation and guidelines. The major aims of people's participation are to make a continuous availability of the basic forest products; socio-economic development of the forest users, and to improve the quality, quantity, and density of forests. Besides, government and I/NGOs could also play a significant role as a facilitator by providing financial, technical and material support.

\section{OBJECTIVES}

The main objective of the present study is to analyze the economic - impact of people's participation in forest management activities of Nepal. So, the paper deals with the economic role of forest products and various factors of people's participation in forest management that determines the gross household income of the local people living in and around the forests in the context of Nepal making a case study of Kabhre Palanchwok.

Rest of the paper is structured as follows: The next section presents short literature review of previous studies; this section is followed by the research methodology, after 
this comes the introduction of the study area. The second last section presents the analysis of data and the final section offers conclusion of the study.

\section{LITERATURE REVIEW}

Forestry plays an important role in the livelihoods of rural people as a source of cash income, capital asset and employment generation (Sunderlin et al., 2003). Rural people could earn cash income through the sale of NTFPs which may account for as much as $16 \%$ of total income of households in India (Mallik, 2000). But in most of the communities, women are primary users and collectors of forest resources like fuel-wood, fodder, grass, fallen leaves and NTFPs for domestic as well as commercial purpose. For rural women, income from non-timber forest products is particularly important. A study in the early 1990's reported that NTFP's accounted for $20 \%$ of household income in West Bengal (Ford Foundation, 1998).

Since the late $20^{\text {th }}$ century, there was a dramatic transformation in global forest resources, their uses, and management system. The global forestry priority also dramatically shifted from forest production to environmental and ecological protection (Houghton, 1990). The 'Jakarta Declaration' of the 'Eighth World Forestry Congress' in 1978 projected serious forest product supply gaps and warned that these could be averted only by ensuring the economic benefits from forest utilization (Chiong-Javier, 2001). Consequently, the century-old centralized and controlled forest management system shifted to decentralization in the form of people's participation. The probable reasons of the change will be the fiscal crisis, structural adjustment, economic liberalization policies, pressure from donor agencies for greater accountability and transparency, the recognition of the failure of past approaches by state agencies, and the demonstration effect of successful pilot efforts by NGOs etc. (Thompson, 1995).

Nepal has also made a significant progress in development of forest resources through the community forestry programme (CFP) in late 1970's due to its nature of operation and procedures (Joshi, 2004). CFP in Nepal is successful in increasing the greenery of degraded sites, biodiversity and environmental situation forming, local level institutions for revenue management and improving the supply of forest products to farmers in the Hills of Nepal (Acharya, 2003). Forestry sector of Nepal accounts for 15 $\%$ of the national GDP (Parajuli, 1997) providing an annual employment to $17.8 \%$ of the economically active population (HMG/N, 1988). However, it is not a substantial to the national GDP in comparison to the contribution from the agricultural sector. It is also estimated that about $61 \%$ (3.5 mha.) of total forest (5.5 mha.) in Nepal is the potential community forest which could be handed over to the local communities for protection, management and sustainable utilization (Tamrakar \& Nelson, 1990). 
Community forestry is clearly contributing to rural people's livelihood (Allison et al., 2004). Forest products are the major source of income of forest user groups (FUGs) which constitutes about $82 \%$ of their total income and community forest is probably contributing about NRs. 2 billion of Nepal's GDP through forest product alone. In many parts of Nepal, up to a quarter of the total household income is derived from the sale of NTFPs (Malla, 2000). Rural Community still consumes $69 \%$ energy from fuel-wood from community forestry and this percentage has not decreased (Shrestha \& Sharma, 2004). The forest use and management would be integrated with strategies of resources use and economic development through the active cooperation and participation of the local people (Nadkarni, 1989). The integration of forest use and management with strategies of economic development is possible only through the active cooperation and participation of the local people (Kandel \& Subedi, 2004).

\section{RESEARCH METHODOLOGY}

\section{Research Design}

The study is designed in accordance with the given objective of the study. So, it is highly based on the primary data of community forest management and various forest products for economic benefits of the local people. The study followed both of descriptive as well as analytical methods. In descriptive method, several socio-economic factors were used in presenting various tabular forms where as in the case of model analysis; it covers only the gross household income of forest products (GHICF).

\section{Sampling Procedure}

Two sampling procedures were followed in which the first stage is selecting 5 forest user groups (FUGs) out of total FUGs of the study area by assuming the similar characteristics of the rest of other FUGs. The second stage was randomly selected fifteen households from each selected FUGs applying lottery method assuming that the selected households would properly represent for the socio-economic diversities of the rest of other households. Therefore, the total sample size turned out 75 households.

\section{Instruments of Collecting Primary Data}

The study used three instruments of collecting primary data. The first instrument is the 'Household Survey' of the randomly selected 75 sampled households in the 5 selected FUGs of the study area through a pre-tested structured questionnaire. The second instrument is the 'Informal Discussion' with the village level representatives, teachers, social workers, senior citizens, former FUG committee members, political leaders, district and range-post level forest officials, and other knowledgeable persons of the study area as key informants in other to develop a better understanding of 
existing forest management systems and practices, and forest products through a set of guidelines. The third instrument is the 'Participatory Observation' in order to verify the collected information with the ground reality like lifestyle of the people, socioeconomic characteristics, pattern of agricultural production, livestock keeping, forest condition, management and conservation practices etc. in the study area. The field survey/visit was carried out by the researcher himself visiting door to door of the selected sampled households with the help of local representatives.

\section{Specification of the Variables and Model}

The study has pursued a multiple log-linear regression line of gross household income from the community forest (GHICF) as a dependent variable and it is the sum of income received from community forest by valuing the direct tangible benefits of collecting and harvesting timber, small timber, pole, firewood, fodder, grass, leaf litter, medicinal plants, herbs, fruits, and nuts etc. So, as the collection of the volume of those forest products increases, the GHICF also increases. However, the GHICF depends upon several independent socio-economic factors like size of land holding (SLH), number of livestock keeping (NLSK), number of household members (NHM), household members involving in forest harvesting (HMFH), women participation in forest management activities (WPFMA), distance between residence and government forest (DRGF), distance between residence and community forest (DRCF), distance between residence and main market (DRMM), people's participation index (PPI) and forest degradation index (FDI). Hence, the general log-linear regression equation (following Gujarati, 2006) is specified as:

$$
\text { h } \mathrm{Y}=\alpha+\beta_{1} \text { h } X_{1}+\beta_{2} \text { h } X_{2}+\ldots+\beta_{n} \text { h } X_{n}+e_{n}
$$

Where, $Y=$ GHICF as dependent variable ; $X_{\mathrm{i}}=$ several independent factors (with, $\mathrm{i}=$ $1,2,3,4, \ldots, \mathrm{n}$ ); $\alpha=$ Constant term , $\beta_{\mathrm{i}}=$ parameters on independent variables (with, $\mathrm{i}$ $=1,2,3,4, \ldots, n) ; e_{n}=$ error term.

\section{Hypotheses of the Study}

The study shows that the availability and use of forest products has a significant relationship with some independent factors as mentioned above but especially the GHICF is significantly affected by the size of land holding (SLD), number of livestock keeping (NLSK), and number of household members (NHM). So, these hypotheses were tested by using t-test for the regression coefficients and F-test for the linearity of the fitted equation (model) at $0.01,0.05$ and 0.10 levels of significance as per the respective degrees of freedom. 


\section{Data Processing and Techniques of Analysis}

After conducting interview from the selected sampled households, the collected data and information were organized and processed through the statistical computer package of 'Microsoft Excel' and 'SPSS' for data analysis. Different types of statistical and econometric tools were used for data analysis and interpretation like coefficient of correlation, multiple regression, coefficient of determinants, adjusted coefficient of determinants, stander error of the parameters, t-test, F-test, auto-correlation etc.

\section{STUDY AREA}

Kabhre Palanchowk district lies in the Central Development Region of Nepal that covers an area of $1446 \mathrm{~km}^{2}$ which is $0.98 \%$ of the nation. It spreads between $27^{\circ} .20^{!}$to $27^{\circ} .35^{\text {! }}$ north latitude and $85^{\circ} .24$ ! to $85^{\circ} .59$ ! east longitude. The elevation of the district varies from $1007 \mathrm{~m}$. to $3018 \mathrm{~m}$. The district is surrounded by Ramechhap in the east, Lalitpur and Bhaktapur in the west, Sindhu-Palchowk in the north and Makwanpur district in the south respectively (CBS, 2001). It has sub-tropical and temperate climate. The center of the district is Dhulikhel which is located at $30 \mathrm{~km}$. east from Kathmandu.

Total population of the district is 3, 85,672 out of which $1,88,947$ (48.99) males and 1 , 96,725 (51.01) females with 70509 households. The total population and households of the district are $1.69 \%$ and $1.68 \%$ of the national figures respectively. The average size of household is 5.47 with the population density is 276 per sq. $\mathrm{km}$. The population growth rate of the district is 1.67 per annum (CBS, 2001).

There are 411 FUGs in Kabhre Palanchowk by $14^{\text {th }}$ August, 2007 (DoF, 2007), out of which 5 FUGs from the district have been randomly selected as sample FUGs for the study like Bhagaban Thumki FUG of Ugratara VDC; Hile Jaljale FUG Tukucha VDC; Kajiko Dhaireni FUG of Panchakhal VDC; Thulophaka-3 FUG of Tukucha VDC and Dhaneshshwor Baikiwa FUG of Panauti Municipality. A brief introduction of those selected five FUGs can be shown with the help of a common outlines of socio-economic profile, bio-physical profile and institutional profile as given below.

\section{a. Socio-economic Profile}

This profile consists of the total household members, total population, distribution of the total household members on the basis of caste, class, religion, occupation, major source of income and community development activities undertaken by the given FUGs etc. as shown in given Table 1. 
Table 1: Socio-economic Profile of Selected FUGs

\begin{tabular}{|c|c|c|c|c|c|c|}
\hline $\begin{array}{l}\mathrm{S} \\
\mathrm{N}\end{array}$ & $\begin{array}{l}\text { Name of FUGs } \\
\text { Particulars }\end{array}$ & $\begin{array}{l}\text { Bhagaban } \\
\text { Thumki }\end{array}$ & Hile Jaljale & $\begin{array}{l}\text { Kajiko } \\
\text { Dhaireni }\end{array}$ & $\begin{array}{l}\text { Thulo } \\
\text { Pakha-3 }\end{array}$ & $\begin{array}{l}\text { haneshwor } \\
\text { Bikiwa }\end{array}$ \\
\hline 1 & $\begin{array}{l}\text { Date of } \\
\text { registration }\end{array}$ & 1990 (2047) & 1991 (2048) & $1993(2050)$ & 1991 (2048) & $2002(2060)$ \\
\hline 2 & $\begin{array}{l}\text { Total HH } \\
\text { members }\end{array}$ & 218 & 242 & 683 & 70 & 164 \\
\hline 3 & $\begin{array}{l}\text { Women Headed } \\
\mathrm{HH}\end{array}$ & 15 & 20 & 25 & 12 & 6 \\
\hline 4 & $\begin{array}{l}\text { Total Population } \\
\text { Male / Female }\end{array}$ & $\begin{array}{c}1231 \\
609 / 622\end{array}$ & $\begin{array}{c}1355 \\
690 / 665\end{array}$ & $\begin{array}{l}4100 \\
2000 / 2100\end{array}$ & $\begin{array}{c}385 \\
188 / 197\end{array}$ & $\begin{array}{c}1027 \\
508 / 519\end{array}$ \\
\hline 5 & Average $\mathrm{HH}$ size & 5.65 & 5.60 & 6 & 5.5 & 6.26 \\
\hline 6 & $\begin{array}{l}\text { Forest Per } \\
\text { Household }\end{array}$ & 0.13 ha. & 0.49 ha. & 0.27 ha. & 0.33 ha. & 0.26 ha. \\
\hline 7 & $\begin{array}{l}\text { Total HH based } \\
\text { on Caste }\end{array}$ & $\begin{array}{l}\text { H.C. }=193 \\
\text { L.C. }=25\end{array}$ & $\begin{array}{l}\text { H.C. }=227 \\
\text { L.C. }=15\end{array}$ & $\begin{array}{l}\text { H.C. }=587 \\
\text { L.C. }=96\end{array}$ & $\begin{array}{l}\text { H.C. }=48 \\
\text { L.C. }=22\end{array}$ & $\begin{array}{l}\text { H.C. }=162 \\
\text { L.C. }=02\end{array}$ \\
\hline 8 & $\begin{array}{l}\text { Total HH based } \\
\text { on Class }\end{array}$ & $\begin{array}{l}\text { Higher }=32 \\
\text { Middle }=61 \\
\text { Poor }=125\end{array}$ & $\begin{array}{l}\text { Higher }=40 \\
\text { Middle= } 110 \\
\text { Poor }=92\end{array}$ & $\begin{array}{l}\text { Higher }=60 \\
\text { Middle= } 310 \\
\text { Poor }=313\end{array}$ & $\begin{array}{l}\text { Higher= } 12 \\
\text { Middle = } 28 \\
\text { Poor }=30\end{array}$ & $\begin{array}{l}\text { Higher }=15 \\
\text { Middle }=60 \\
\text { Poor }=89\end{array}$ \\
\hline 9 & $\begin{array}{l}\text { Total HH based } \\
\text { on Religion }\end{array}$ & Hindu $=218$ & $\begin{array}{l}\text { Hindu= } 239 \\
\text { Buddhist }=3\end{array}$ & $\begin{array}{l}\text { Hindu }=653 \\
\text { Buddhist=30 }\end{array}$ & $\begin{array}{l}\text { Hindu }=64 \\
\text { Buddhist }=6\end{array}$ & $\begin{array}{l}\text { Hindu }=164 \\
\text { Buddhist }=0\end{array}$ \\
\hline 10 & $\begin{array}{l}\text { Total HH } \\
\text { based on Major } \\
\text { Occupation. }\end{array}$ & \begin{tabular}{|l} 
Agri. $=143$ \\
Livestock=10 \\
Business = 10 \\
Services = 55
\end{tabular} & $\begin{array}{l}\text { Agri. = } 195 \\
\text { Livestock=17 } \\
\text { Business =25 } \\
\text { Services =15 }\end{array}$ & $\begin{array}{l}\text { Agri. }=558 \\
\text { Livestock=50 } \\
\text { Business }=20 \\
\text { Services }=55\end{array}$ & $\begin{array}{l}\text { Agri. }=40 \\
\text { Livestock }=13 \\
\text { Business }=12 \\
\text { Services }=5\end{array}$ & $\begin{array}{l}\text { Agri. }=79 \\
\text { Livestock }=53 \\
\text { Services }=32\end{array}$ \\
\hline 11 & $\begin{array}{l}\text { Major source of } \\
\text { income }\end{array}$ & $\begin{array}{l}\text { sale of forest } \\
\text { products, } \\
\text { membership } \\
\text { fee and fine }\end{array}$ & $\begin{array}{l}\text { sale of forest } \\
\text { products, } \\
\text { membership } \\
\text { fee and fine } \\
\end{array}$ & $\begin{array}{l}\text { sale of forest } \\
\text { products, } \\
\text { membership } \\
\text { fee, and fine } \\
\end{array}$ & $\begin{array}{l}\text { sale of forest } \\
\text { products, } \\
\text { membership } \\
\text { fee and fine }\end{array}$ & $\begin{array}{l}\text { sale of forest } \\
\text { products, } \\
\text { membership } \\
\text { fee and fine }\end{array}$ \\
\hline 12 & $\begin{array}{l}\text { Community } \\
\text { Development } \\
\text { Activities }\end{array}$ & $\begin{array}{l}\text { school, } \\
\text { college, } \\
\text { electricity }\end{array}$ & $\begin{array}{l}\text { water supply } \\
\text { school, } \\
\text { temple }\end{array}$ & $\begin{array}{l}\text { school, } \\
\text { temple, } \\
\text { road }\end{array}$ & \begin{tabular}{|l|} 
road, light \\
irrigation, \\
school, \\
temple \\
\end{tabular} & No major \\
\hline
\end{tabular}

Source: FUG Office, 2006. Note: HH means household.

\section{b. Bio-physical Profile}

The second profile is related to the physical structure and the condition of the forests on the basis of the number and nature and availability of bio-diversity of the forests as shown in given Table 2 . 
Table 2: Bio-physical Profile of Selected FUGs

\begin{tabular}{|c|c|c|c|c|c|c|}
\hline $\begin{array}{l}S \\
N\end{array}$ & $\begin{array}{c}\text { Name of } \\
\text { FUGs Particulars }\end{array}$ & $\begin{array}{l}\text { Bhagaban } \\
\text { Thumki }\end{array}$ & Hile Jaljale & $\begin{array}{l}\text { Kajiko } \\
\text { Dhaireni }\end{array}$ & $\begin{array}{l}\text { Thulo } \\
\text { Pakha-3 }\end{array}$ & $\begin{array}{l}\text { Dhaneshwori } \\
\text { Wikiwa }\end{array}$ \\
\hline 1 & Forest area & 29 ha & 118 ha & 182 ha & 23 ha & 43 ha \\
\hline 2 & Vegetation types & Pine forest & Pine forest & Pine forest & Pine forest & Schima forest \\
\hline 3 & Forest types & $\begin{array}{l}\text { Natural + } \\
\text { Plantation }\end{array}$ & $\begin{array}{l}\text { Natural + } \\
\text { Plantation }\end{array}$ & $\begin{array}{l}\text { Natural + } \\
\text { Plantation }\end{array}$ & $\begin{array}{l}\text { Natural + } \\
\text { Plantation }\end{array}$ & $\begin{array}{l}\text { Natural + } \\
\text { Plantation }\end{array}$ \\
\hline 4 & $\begin{array}{l}\text { Topography of } \\
\text { forests }\end{array}$ & $\begin{array}{l}\text { Slightly } \\
\text { sloppy }\end{array}$ & Sloppy & Sloppy & Sloppy & $\begin{array}{l}\text { Slightly } \\
\text { sloppy }\end{array}$ \\
\hline 5 & $\begin{array}{l}\text { Major tree species } \\
\text { Availability. }\end{array}$ & $\begin{array}{l}\text { chilauni, } \\
\text { setikath salla, }\end{array}$ & $\begin{array}{l}\text { salla, } \\
\text { chilauni, } \\
\text { setikath }\end{array}$ & $\begin{array}{l}\text { saal, salla, } \\
\text { katus, simal }\end{array}$ & $\begin{array}{l}\text { salla, } \\
\text { setikath } \\
\text { chilauni, }\end{array}$ & $\begin{array}{l}\text { katus, salla, } \\
\text { gurans }\end{array}$ \\
\hline 6 & $\begin{array}{l}\text { Major fodder } \\
\text { species availability. }\end{array}$ & $\begin{array}{l}\text { Katus, } \\
\text { Chilaune }\end{array}$ & Khanun & Katus & Chilauni & Katus \\
\hline 7 & $\begin{array}{l}\text { Major animal } \\
\text { species availability }\end{array}$ & $\begin{array}{l}\text { Porcupine, } \\
\text { Fox }\end{array}$ & $\begin{array}{l}\text { Tiger, Fox, } \\
\text { Porcupine }\end{array}$ & $\begin{array}{l}\text { Tiger, Fox } \\
\text { Leopard, }\end{array}$ & Tiger, Fox & $\begin{array}{l}\text { Tiger, Fox } \\
\text { Leopard, }\end{array}$ \\
\hline 8 & $\begin{array}{l}\text { Major bird species } \\
\text { availability }\end{array}$ & $\begin{array}{l}\text { Forest cock, } \\
\text { Pheasant, }\end{array}$ & $\begin{array}{l}\text { Forest cock, } \\
\text { dove, cuckoo }\end{array}$ & Dove, Eagle & $\begin{array}{l}\text { Dove, } \\
\text { Parrot }\end{array}$ & $\begin{array}{l}\text { Forest cock, } \\
\text { Parrot }\end{array}$ \\
\hline 9 & $\begin{array}{l}\text { Major NTFPs } \\
\text { availability }\end{array}$ & $\begin{array}{c}\text { Bamboo, } \\
\text { Aiselu, } \\
\text { Nigalo Khoto }\end{array}$ & $\begin{array}{c}\text { Dhasigare, } \\
\text { Nigalo, } \\
\text { Chttro }\end{array}$ & $\begin{array}{c}\text { Dhasigare, } \\
\text { Gurans, } \\
\text { Chttro }\end{array}$ & $\begin{array}{c}\text { Dhasigare, } \\
\text { Kaphal, } \\
\text { Chttro }\end{array}$ & $\begin{array}{l}\text { Dhasigare, } \\
\text { Bamboo, } \\
\text { Gurans }\end{array}$ \\
\hline 10 & $\begin{array}{l}\text { Major medicinal } \\
\text { plant availability }\end{array}$ & $\begin{array}{l}\text { Dhasigare, } \\
\text { Chutro }\end{array}$ & $\begin{array}{l}\text { Amala, } \\
\text { Pashwonbed }\end{array}$ & $\begin{array}{l}\text { Dhasigare, } \\
\text { Chutro } \\
\text { Amala }\end{array}$ & $\begin{array}{l}\text { Dhasigare, } \\
\text { Chutro }\end{array}$ & $\begin{array}{l}\text { Dhasigare, } \\
\text { Chutro }\end{array}$ \\
\hline 11 & Forest condition * & Good & Very Good & Good & Good & Good \\
\hline 12 & Dist from $\mathrm{CF}$ to $\mathrm{GF}$ & $6 \mathrm{~km}$. & Adjoined & $8 \mathrm{~km}$. & $4 \mathrm{~km}$ & $2 \mathrm{~km}$. \\
\hline 13 & $\begin{array}{l}\text { Dist from CF to } \\
\text { centre }\end{array}$ & $3 \mathrm{~km}$. & $5 \mathrm{~km}$. & $23 \mathrm{~km}$. & $4.5 \mathrm{~km}$. & $1 \mathrm{~km}$. \\
\hline
\end{tabular}

Source: FUG Office, 2006.

\section{c. Institutional Profile}

The next is the institutional profile that comprises the structure of the FUGs on the basis of the nature of membership in general body and executive committee, meeting conducting in a year etc. as shown in given Table 3. 
Table 3: Institutional Profile of Selected FUGs

\begin{tabular}{|l|l|c|c|c|c|c|}
\hline $\begin{array}{l}\text { S } \\
\text { N }\end{array}$ & $\begin{array}{l}\text { Name of the UGs } \\
\text { Particulars }\end{array}$ & $\begin{array}{c}\text { Bhagaban } \\
\text { Thumki }\end{array}$ & Hile Jaljale & $\begin{array}{c}\text { Kajiko } \\
\text { Dhaireni }\end{array}$ & $\begin{array}{c}\text { Thulo } \\
\text { Pakha-3 }\end{array}$ & $\begin{array}{c}\text { Dhaneshwor } \\
\text { Bikiwa }\end{array}$ \\
\hline 1 & HH membership & one M or F & one M or F & one M or F & one M or F & one M or F \\
\hline 2 & EC Members & 11 & 11 & 13 & 11 & 13 \\
\hline 3 & Chairperson & Selection & Selection & Selection & Selection & Election \\
\hline 4 & Other members & Nomination & Nomination & Nomination & Nomination & Nomination \\
\hline 5 & Member Secretary & Selection & Selection & Selection & Selection & Selection \\
\hline 6 & $\begin{array}{l}\text { Female member } \\
\text { in EC }\end{array}$ & 3 & 3 & 3 & 3 & 3 \\
\hline 7 & Given period of EC & 5 Years & 3 Years & 2 Years & 5 & 2 \\
\hline 8 & Meeting of EC & Once/ month & Once/ month & Once/month & $\begin{array}{c}\text { Once/ } \\
\text { month }\end{array}$ & $\begin{array}{c}\text { Once a } \\
\text { month }\end{array}$ \\
\hline 9 & $\begin{array}{l}\text { Meeting of Gen. } \\
\text { Body }\end{array}$ & Twice a year & Twice a year & Once a year & Once a year & Once a year \\
\hline 10 & $\begin{array}{l}\text { Forest Guard / } \\
\text { Salary }\end{array}$ & One / FUG & One / FUG & One / FUG & One / FUG & One / FUG \\
\hline
\end{tabular}

Source: FUG Office, 2006. Note: $H H=$ household, $M=$ male, $F=$ female, $E C=$ exe. committee.

\section{DATA ANALYSIS AND INTERPRETATION}

In the study area, the sample households are generally collect the forest products like timber, fuel wood, fodder, grasses, and life litter. Community forests have directly or indirectly provided income and employment opportunities to the user groups in making closures of forests, plantation, silvicultural (like thinning, pruning and weeding), local infrastructure development activities, livestock keeping, cottage industry, and forest guard etc. Hence, it shows that community forestry is providing income generation and employment opportunities to the member households of FUGs. It means the household's economic activity is the function of the use of forest resources and forest management. Similarly, some factors related to physical environment like the distance between the residence to community forests, government forests and main market etc. In addition, some factors like area under forests, its density and geographical features might be some other important determinants. In this study, however, the income generation through the basic forest products and forest management are taken as the gross household income from community forests (GHICF).

So, the GHICF is taken as the dependent (response) variable and some social, economic, physical and environmental factors are taken as independent (explanatory) variables like the size of land holding (SLD), number of livestock keeping (NLSK), 
total household members (THM), household members in forest harvesting (HMFH), women participation in forest management activities (WPFMA), distance between the residence and government forest (DRGF), distance between the residence and community forest (DRCF), distance between the residence and main market (DRMM), people's participation index (PPI) and forest degradation index (FDI). But other variables that may significantly affect to the process of GHICF are not included in the model due to some constraints of the study. Therefore, a log-linear multiple regression model is drawn in order to observe the degree of change in GHICF with any change in the given explanatory variables as given in Table 4 .

Table 4: Results of Regression Analysis for Determinants of GHICF

\begin{tabular}{|c|c|c|c|c|c|}
\hline \multirow{2}{*}{$\begin{array}{c}\text { Constant and } \\
\text { Coefficients }\end{array}$} & \multirow{2}{*}{$\begin{array}{c}\text { Expected } \\
\text { Sign }\end{array}$} & \multicolumn{3}{|c|}{ Kabhre Palanchwok } & $\begin{array}{l}\text { Summary } \\
\text { Statistics }\end{array}$ \\
\hline & & Values & $\begin{array}{l}\text { Standard } \\
\text { Error }\end{array}$ & $\mathrm{t}$-value & \multirow{12}{*}{$\begin{array}{l}\mathrm{r}=0.540 \\
\mathrm{R}^{2}=0.292 \\
\text { Adj. } \mathrm{R}^{2}=0.181 \\
\mathrm{~F}-\mathrm{value}=2.633 \text { ** } \\
\mathrm{D}-\mathrm{W} \text { value }=2.669 \\
\mathrm{~N}=75\end{array}$} \\
\hline Constant $\left(\beta_{0}\right)$ & & 1.923 & 1.417 & 1.357 & \\
\hline $\operatorname{SLD}\left(\beta_{1}\right)$ & + & 0.502 & 0.141 & $3.568^{*}$ & \\
\hline $\operatorname{NLSK}\left(\beta_{2}\right)$ & + & 0.038 & 0.188 & $2.200^{* *}$ & \\
\hline $\operatorname{THM}\left(\beta_{3}\right)$ & + & -0.282 & 0.296 & -0.953 & \\
\hline $\mathrm{HMFH}\left(\beta_{4}\right)$ & + & 0.220 & 0.359 & $2.613^{* *}$ & \\
\hline WPFMA $\left(\beta_{5}\right)$ & + & 0.119 & 0.351 & $2.338^{* *}$ & \\
\hline $\operatorname{DRGF}\left(\beta_{6}\right)$ & + & 0.282 & 0.310 & $2.912^{* *}$ & \\
\hline $\operatorname{DRCF}\left(\beta_{7}\right)$ & - & -0.060 & 0.189 & $-2.317^{* *}$ & \\
\hline $\operatorname{DRMM}\left(\beta_{8}\right)$ & + & 0.236 & 0.148 & $1.660^{* * *}$ & \\
\hline PPI $\left(\beta_{q}\right)$ & + & 0.358 & 0.355 & $2.008^{* *}$ & \\
\hline FDI $\left(\beta_{10}\right)$ & - & -0.650 & 0.994 & $1.764^{* * *}$ & \\
\hline
\end{tabular}

Note: ${ }^{*}$ Significant at $1 \%,{ }^{* *}$ Significant at $5 \%,{ }^{* * *}$ Significant at $10 \%$.

The results given in Table 4 reveals that around $29.2 \%$ of the total variation in the response (dependent) variable (GHICF) is explained by the variation in the given explanatory (independent) variables. Similarly, $18.1 \%$ of the total variation in the response (dependent) variable (GHICF) is explained by the fitted regression equation.

Again the calculated F-value for overall goodness of fit in the model is greater than its tabulated value $\left(\mathrm{F}_{\mathrm{cal}}>\mathrm{F}_{\mathrm{tab}}\right)$ at $5 \%$ level of significance. Hence, it could be concluded that the regression equation is statistically significant by rejecting null hypothesis of the study.

Similarly, all predictors in the model (except THM) came out with the expected sign of coefficients which show that a unit increase in any of predictor with positive sign leads 
to increase in the response (dependent) variable by the respective percentage as shown in given table holding other variables constant. Similarly, the predictor of DRCF and FDI in the model came out with the expected negative sign of the coefficients which show that a unit decrease in such variable leads to increase in response variable by the given percentage as shown in given table holding other variables constant. Infect, those are the favorable results.

But having the unexpected negative sign of THM in the model is theoretically opposite results as one unit increase in THM leads to reduce the GHICF by $28.2 \%$. Hence, the result of unexpected sign of coefficient may be due to the existence of multicollinearity problem among the given explanatory variables.

Similarly, as the calculate $t$-value of all variables in the model (except THM) is greater than its tabulated value $\left(t_{\mathrm{cal}}>t_{\mathrm{tab}}\right)$, these are statically significant even at $1 \%$ level of significance by rejecting null hypothesis for all those variables.

But, the t-value of coefficients of THM in the model is less than its tabulated value even at $10 \%$ level of significance. Hence, null hypothesis is accepted by concluding that the regression coefficient is statistically insignificant. It concludes that these variables are not significantly affecting the level of GHICF. It may be due to existence of either inappropriate number of household members in forest harvesting or carelessness of number of participation in forest harvesting or using incorrect method of forest harvesting or incorrect and insufficient available data.

Similarly, the calculated D-W value of the model is greater than its tabulated value at upper level $\left(D-W>d_{U}\right)$ at $5 \%$ level of significance. Hence, it concludes that the error terms in the model is said to be no positively auto-correlated.

\section{CONCLUSION}

People's participation has become the most effective vehicle for forest protection, management, sustainable development, environmental protection, ecological promotion and biodiversity conservation. As people are highly dependent upon forests and forest products for income and employment generation, they do more participate in forestry program. The GHICF is determined by many variables out of which the size of land holding (SLH), number of livestock keeping (NLSK), total household members (THM), and distance between residence and community forests (DRCF) and overall forest condition (FDI) are the major ones. The role of forest department should not be as police but as a partner, advisor, facilitator and more technical supporter. Moreover, the role of I/NGOs and other stakeholders as advisor and facilitator should not be ignored in forestry programmes for effective people's participation. However, the major challenges of CFM in Nepal at present are how to make meaningful involvement of local people in better forest protection, management 
and sustainable development so that they will get sustainable economic benefits for income and employment generation, socio-economic development, poverty reduction, and environmental protection and ecological balance.

\section{References}

Acharya, K. P. (2003).Twenty-four years of community forestry in Nepal, paper presented in a project evaluation workshop on community forestry. Kathmandu, Nepal: DoF, His Majesty's Government of Nepal.

Allison, G., Bampton, J., Kanel, B. R., Shrestha, M. L \& Shrestha, N. K. (2004). Community forestry and livelihoods: How can community forestry better contribute to the millennium development goals? Twenty five years of community forestry: Contributing to millennium development goals, Katmandu, Nepal: Community Forestry Division, Department of Forest.

CBS (2001). Statistical Year Book, National Planning Commission Secretariat. Thapathali, Kathmandu: His Majesty's Government of Nepal.

Chiong-Javier, M. (2001). Local organizations in upland natural resource management in the Philippines: Country overview, Paper Presented at the SANREM Conference on Local Governance of Natural Resource Management in Southeast Asia, Makati, Manila, May, 28-30.

DoF (1999). Forest resources of Nepal (1987-1998). Department of Forest Research and Survey. Ministry of Forests and Soil Conservation. Kathmandu, Nepal: His Majesty's Government of Nepal.

DoF (2007). FUG database record available in MIS, Community Forest Division, Department of Forest. Kathmandu, Nepal. Ministry of Forests and Soil Conservation,

Ford Foundation (1998). Forestry for sustainable rural development: a review of ford foundationsupported community forestry programme in Asia. New York: Ford Foundation

Gujarati, D. N. (2006). Basic econometrics (4 ${ }^{\text {th }}$ ed.). New Delhi: Tata McGraw-Hill Publishing Company Limited.

HMG/N (1988). Master plan for the forestry sector. Kathmandu, Nepal: His Majesty's Government, Ministry of Forest and Soil Conservation,

Houghton, R. A. (1990). The global effects to tropical deforestation. Environmental science and technology, 24, 414-424

Joshi, D. B. (2004). Programme planning in community forestry. Community Forestry Bulletin, DoF, HMG, Kathmandu, Nepal. Vol.11, 20-33.

Kandel, B. R., \& Subedi, R. (2004). Pro-poor community forestry: Some initiatives from the field, Paper Presented at the $4^{\text {th }}$ National Workshop on Community Forestry, DoF, HMG, Kathmandu, Nepal.

Malla, Y. B. (2000). Impact of community forestry policy on rural livelihoods and food security in Nepal. Unasylva, 51(202), 37-45.

Mallik, R. M. (2000). Sustainable management of non-timber forest products in Orissa: Some issues and options. Indian Journal of Agricultural Economics, 55(3), 383- 397. 
Nadkarni, M. V. (1989). The political economy of forest use and management. New Delhi, India: Sage Publication,

Parajuli, D. P. (1997). Analysis of Forest Policy in Nepal. In S. Gyawali, K. Baral \& C. Khatiwada (Eds.), Prabhat, (pp. 9-16). Pokhara, Nepal: Annual Publication, Institute of Forestry Vol: 5 .

Shrestha, R. B. \& Sharma, A. R. (2004). Sustainable management of community forests: Contribution towards millennium development goals. Paper Presented to the $4^{\text {th }}$ National Workshop on community forestry, 4-6 August, DoF, HMG, Kathmandu, Nepal.

Sunderlin, W., Angelsen, A. \& Wunder, S. (2003). Forests and poverty alleviation. In FAO, State of the World's Forests -2003, Food and Agriculture Organization of the United Nations, Rome, Italy, (pp. 61-73).

Tamrakar, S. M. \& Nelson, D. V. (1990). Potential community forestry land in Nepal, part 1 and 2. Field document no 16. Kathmandu, Nepal: HMG/N / FAO / UNDP.

Thompson, J. (1995).Participatory approaches in government bureaucracies: Facilitating the process of institutional change. World Development, 23, 1521-1534. 